\title{
Effect of sprinkler and drip irrigation systems on seed yield and quality of oil for some sunflower genotypes
}

\author{
Ahmed A.A., K.M. Aboelkassem* and E.M.M. Elnenny \\ Oil crops Research Department, Field Crops Research Institute, Agriculture Research Center, Giza, Egypt.
}

\begin{abstract}
A field experiment was performed at the Arb El-Awamer Research Station, Assuit Governorate, Agricultural Research Center, Egypt during the two consecutive summer seasons of 2017 and 2018 to achieve the highest yield and good oil quality of nine tested sunflower genotypes. In both seasons, the experiment was conducted using the split plot design in randomized complete block design with three replicates arrangement keeping irrigation system (sprinkler and drip) in the main plots, and sunflower genotypes (L990, L770, L465, L125, L460, L880, L120, Giza 102 and Sakha 53) in the sub plots. Yield and quality traits were significantly influenced by irrigation system and genotypes as well as their interactions in both seasons and their combined analysis. The drip irrigation system seems to be a good compromise between the highest seed yield /fedden and good fatty acid composition of oil. Line 120 was ranked in the first order in head diameter, 100-seed weight, seed weight /plant, flowered late and hence seed yield /fedden, as well as seed oil content, whereas, Sakha 53 characterized with it contained the highest proportion of unsaturated fatty acids. The highest values of head diameter, 100-seed weight, seed weight /plant and hence seed yield /fedden as well as the highest proportion of unsaturated fatty acids composition were obtained by grown sunflower L120 at drip irrigation system.
\end{abstract}

Keywords: Drip irrigation; Fatty acids; Seed yield; Sprinkler irrigation; Sunflower Genotypes.

\section{Introduction}

Sunflower (Helianthus annuus L.) is one of the most important industrial crops in the world because it's edible vegetable oil, after soybean (Putt, 1997; Fernandez - Martinez at al., 2004; Hu et al., 2010). Helianthus annuus $L$. is a diploid plant with $2 \mathrm{n}=34$ chromosomes (Fick, 1989). Sunflower oil is widespread

\footnotetext{
*Corresponding author: K.M. Aboelkassem

Email: khaled aboelkassem@hotmail.com

Received: May 5, 2021; Accepted: June 9, 2021;

Published online: June 21, 2021.

(c) Published by South Valley University.

This is an open access article licensed under @()-()
}

because high quality and is one of the five basic nutrients for human food (Demirer $e t$ al., 2004). The main objective in many researches is to evaluate the agronomic properties for commercial sunflower cultivars (Killi and Altunbay, 2005; Sadghi et al., 2008; Karaaslan et al., 2010). According to Merren and Champolivier (1992) the most important yield components are number of plants per unit area, number of seeds per unit area and mass of seeds. On the other hand, oil content in sunflower seed is one of the most important agronomic traits. According to 
Keshta et al., (2008), the percentage of oil is between $38.0 \%-54.4 \%$. The values of oil content and seed yield depend on genotype and environmental conditions in which genotypes are grown. Among the abiotic factors, during the sunflower growing period, drought stress is limiting factor. Sunflower yield can be reduced by water deficit approximately 15 - 50\% (Nagarathna et al., 2012) and this factor is one of the major limitations in other crop yield. On the other hand, considered the declining potential of irrigation water and due to the rising demand for water from various fields, a variety of demand management strategies and programs have been implemented in agriculture to conserve water and improve current water use quality. The demand for water is increasing every passing hour due to agricultural use, urbanization and unsustainable use. Its per capita availability has decreased dramatically throughout the world. It is common knowledge that agriculture is the largest consumer of water and tends to control public needs. Therefore, emphasis must be placed on implementing modern irrigation methods that are effective in saving water and increasing crop water production such as sprinkler and drip irrigation. However, the acceptability of these methods depends on their success in terms of maximum yields associated with minimal water use. The aim of this paper was to evaluate the production potential and quality of some sunflower varieties under the sprinkler and drib irrigation systems.

\section{Materials and Methods}

Nine sunflower genotypes from different sources (Table 1) were sown at the experimental farm of Arb El-Awamer Agricultural Research Center Assuit, Egypt during the two growing summer seasons; 2017 and 2018 to achieve the highest yield and good oil quality. (Table 2) shows chemical and physical properties of the soil. Saturation extracts conductivity (EC), pH, cations and anions of experimental sites were analyzed according to Page et al., (1982) and chemical analysis of the irrigation water. The irrigation water was slightly saline (EC 4.6 $\mathrm{dSm}-1)$. The wheat was the previous crop in both seasons. The experiment was conducted in a split-plot Design in randomized complete block with three replicates arrangement keeping irrigation systems (sprinkler and drip) in the main plots, and sunflower genotypes (L990, L770, L465, L125, L460, L880, L120, Giza 102 and Sakha 53) in subplot. Each plot area was $10.5 \mathrm{~m}^{2}(3 \times 3.5 \mathrm{~m})$ and included 5 rows $3 \mathrm{~m}$ long and $70 \mathrm{~cm}$ plant spacing's of $30 \mathrm{~cm}$. The sowing dates were May 2017 and 2018, respectively and harvested at plant maturity. Throughout the season, all plots were irrigated as needed. During the growing season, the plot was also kept free of rodents, diseases, and weeds. The recommended fertilization for this type of soil was applied as follows: Organic fertilization (20 $\mathrm{m}^{3} /$ feddan $)$ during soil preparation, $\mathrm{Ca}\left(\mathrm{H}_{2} \mathrm{PO}_{4}\right)_{2}\left(45 \mathrm{~kg} \mathrm{P}_{2} \mathrm{O}_{5}\right.$ / fedden) before sowing, and $\mathrm{NH}_{4} \mathrm{NO}_{3}$ and $\mathrm{K}_{2} \mathrm{SO}_{4}(50 \mathrm{~kg} / \mathrm{fed}$ each 3 times, at 2, 4 and 6 weeks after sowing). 
Table 1. Pedigree of 9 sunflower genotypes studied.

\begin{tabular}{ccc}
\hline No & Genotypes & Pedigree \\
\hline 1 & L990 & Bulgarian $59 \times$ Bulgarian 52 \\
2 & L770 & Bulgarian $53 \times$ Bulgarian 49 \\
3 & L465 & Bulgarian $53 \times$ Bulgarian 52 \\
4 & L125 & Mayak $\times$ Bulgarian3 \\
5 & L460 & Bulgarian $51 \times$ Bulgarian 52 \\
6 & L 880 & Bulgarian $54 \times$ Bulgarian 52 \\
7 & L120 & Mayak $\times$ Bulgarian2 \\
8 & Giza 102 & Giza \\
9 & Sakha 53 & Mayak $\times$ Bulgarian1 \\
\hline
\end{tabular}

Table 2. Chemical and physical properties of the soil at Arb El-Awamer Research station

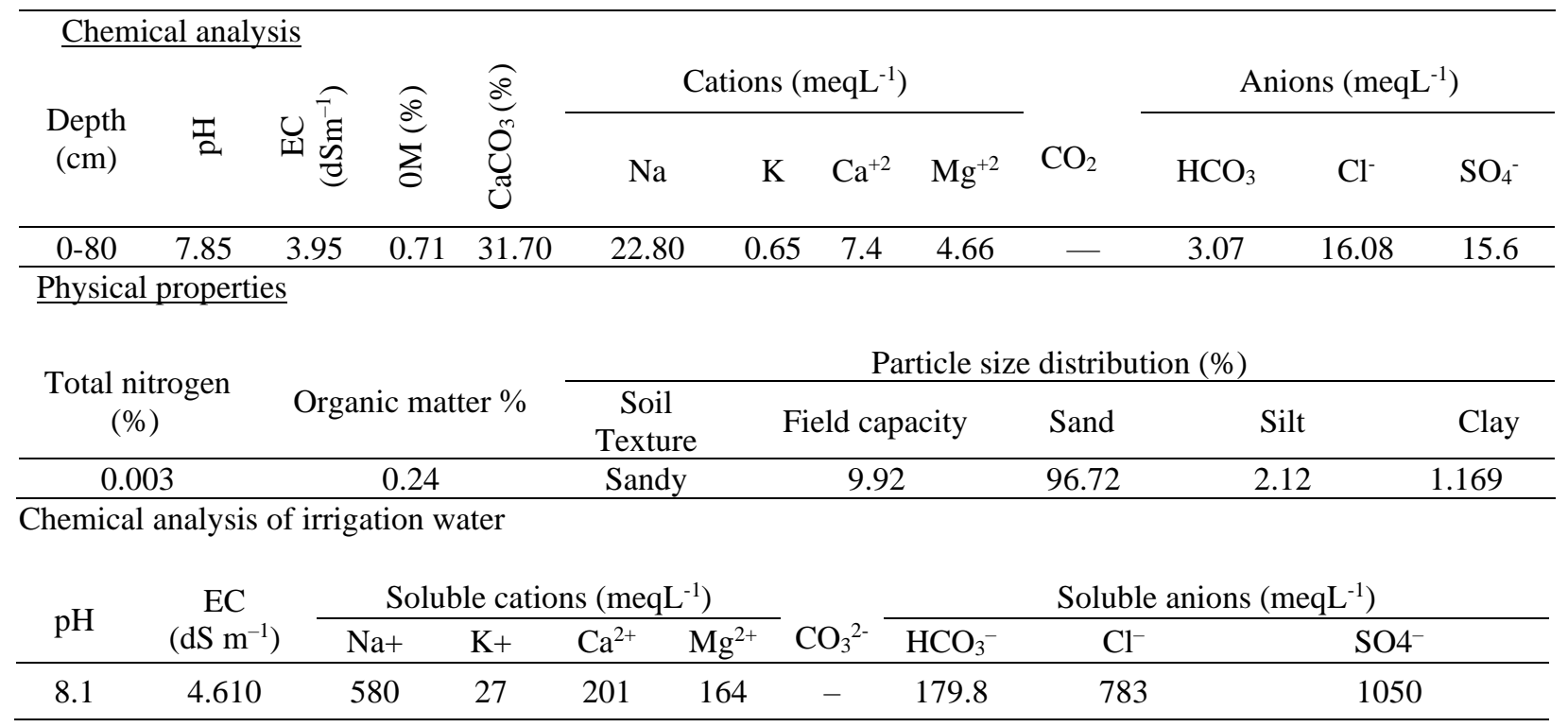

\subsection{Data collected}

\subsubsection{Yield and yield attributes}

For each split-plot, the number of days to $50 \%$ flowering was recorded as the flowering date. During the harvest, five guarded plants were randomly selected from the $2^{\text {nd }}$ and $4^{\text {th }}$ ridges, harvested, tied and left to head dry to determine yield and yield attributes viz. plant height in $\mathrm{cm}$, stem diameter in $\mathrm{cm}$, head diameter in cm, 100-seed weight in gram and seed weight /plant in gram. Each split plot's central ridge plants were harvested to determine seed yield per $\mathrm{m}^{2}$, which was then converted to recorded seed yield in $\mathrm{kg} /$ fedden.

\subsection{Chemical composition of seeds}

Samples of seeds were oven dried, ground finely and stored in small bags for chemical 
analysis. Extraction of oils, the method used to determine in the seed was the Association of Official Analytical Chemists (AOAC, 2005). According to AOAC (1990) oil percentage was determined. The method used to determine total protein in the seed was AOAC (2000). Gas liquid chromatography (Aglent 6890 GC, USA) used for determination and identification of the fatty acids composition, in Central Laboratory of Food Technology Research Institute, ARC, Egypt, according to Zygadlo et al., (1994). According to Gomez and Gomez (1984), all data obtained in this analysis of each season was analyzed. As defined by Gomez and Gomez (1984), Homogeneity of variance between two seasons was checked as described.

\section{Results and discussion}

\subsection{Effect of irrigation systems}

\subsubsection{Yield and yield attributes}

Data in (Table 3) show the combined analysis and showed that sprinkler and drip irrigation

Table 3. Effect of irrigation system on growth characters in the two Season of 2017 and 2018 and their combined

\begin{tabular}{|c|c|c|c|c|c|c|c|}
\hline Irrigation & $\begin{array}{l}50 \% \\
\text { flowering }\end{array}$ & $\begin{array}{l}\text { Plant } \\
\text { height }(\mathrm{cm})\end{array}$ & $\begin{array}{l}\text { Stem } \\
\text { diameter } \\
(\mathrm{cm})\end{array}$ & $\begin{array}{l}\text { Head } \\
\text { diameter } \\
(\mathrm{cm})\end{array}$ & $\begin{array}{l}100 \text {-seed } \\
\text { weight }(\mathrm{g})\end{array}$ & $\begin{array}{l}\text { Seed } \\
\text { yield } \\
\text { (g/plant) }\end{array}$ & $\begin{array}{l}\text { Seed yield } \\
\text { (kg/ fedden) }\end{array}$ \\
\hline \multicolumn{8}{|c|}{2017 season } \\
\hline Sprinkler & 44.53 & 141.80 & 2.01 & 17.49 & 5.64 & 39.89 & 1167.81 \\
\hline Drip & 46.63 & 144.14 & 2.26 & 17.46 & 5.85 & 47.35 & 1226.04 \\
\hline LSD & 1.35 & 1.20 & 0.02 & N.S & 0.10 & 1.76 & 23.07 \\
\hline \multicolumn{8}{|c|}{2018 season } \\
\hline Sprinkler & 45.00 & 142.73 & 1.97 & 17.52 & 5.75 & 40.11 & 1179.31 \\
\hline Drip & 47.46 & 145.33 & 1.88 & 17.57 & 5.74 & 46.65 & 1187.95 \\
\hline LSD & 0.62 & 1.15 & 0.07 & N.S & N.S & 0.06 & N.S \\
\hline \multicolumn{8}{|c|}{ Combined } \\
\hline Sprinkler & 44.76 & 142.27 & 1.99 & 17.51 & 5.70 & 40.00 & 1173.57 \\
\hline Drip & 47.05 & 144.74 & 2.07 & 17.52 & 5.79 & 47.00 & 1207.00 \\
\hline LSD & 0.48 & 0.54 & 0.06 & N.S & 0.05 & 0.56 & 8.02 \\
\hline
\end{tabular}

system was significant different in each of number of days to $50 \%$ flowering, plant height, stem diameter, 100-seed weight, seed yield /plant and then seed yield /fedden except head diameter on both seasons and their combined as well as 100-seed weight and seed yield / fedden on the second season which were not significand regarding irrigation system. The drip irrigation system clearly gave the highest values for yield and its attributes, as shown in the combined analysis. It can be seen that drip irrigation and sprinkler irrigation methods yield 1207.00 and $1173.57 \mathrm{~kg} /$ fedden, respectively. As mentioned by Abdul Latif et al., (2015) the increase in sunflower yield from drip irrigation was due to specific irrigation management that resulted in a radial distribution pattern and efficient nutrient fertigation in the wetted soil volume, where the majority of the roots are connected near the emitter or along each lateral line. 


\subsubsection{Chemical composition of seeds}

It is evident from the data given in (Table 4), that a significant effect of drip and sprinkler irrigation system was noticed on proportion

Table 4. Effect of irrigation systems on chemical composition of seeds in the two seasons of 2017 and 2018 and their combined

\begin{tabular}{ccccc}
\hline Traits & $\begin{array}{c}\text { Oil percentage } \\
(\%)\end{array}$ & Total protein $(\%)$ & $\begin{array}{c}\text { Saturated fatty acid } \\
(\%)\end{array}$ & $\begin{array}{c}\text { Unsaturated fatty } \\
\text { acid }(\%)\end{array}$ \\
\hline Sprigation & 39.00 & 2017 season & & \\
Drip & 39.40 & 18.32 & 14.44 & 85.56 \\
LSD & 0.25 & 0.18 & 15.26 & 84.74 \\
& & 2018 season & 0.13 & 0.13 \\
Sprinkler & 39.48 & 18.38 & 14.30 & 85.70 \\
Drip & 39.66 & 18.45 & 14.72 & 85.28 \\
LSD & N.S & N.S & N.S & N.S \\
& & Combined & & 85.63 \\
Sprinkler & 39.24 & 18.35 & 14.37 & 85.01 \\
Drip & 39.53 & 18.51 & 14.99 & 0.24 \\
LSD & 0.09 & 0.09 & 0.24 & \\
\hline
\end{tabular}

of oil, protein, saturated fatty acid and unsaturated fatty acid. The results indicated an increase in the percentage of oil, protein and saturated fatty acid under drip irrigation system, while the unsaturated fatty acid recorded an increase under sprinkler irrigation system in 2017 season and combined analysis. While the results were not significant in 2018 season similar result was also reported by Kassab et al. (2012).

\subsection{Tested sunflower genotypes effect}

\subsubsection{Yield and yield component}

The data in (Table 5) demonstrates that significant differences were detected among the nine tested sunflower genotypes with respect to yield and yield attributes in both seasons and their combined analysis. Hence, possibility of improvement for these traits within these breeding materials was effective. From the combined review, it can be deduced that L120 scored the highest head diameter $(19.32 \mathrm{~cm}), 100$-seed weight $(6.65$ g), seed yield /plant (47.38 g) and seed yield /Fedden (1360.75 kg), while it was latest in $50 \%$ flowering (47.75 days). On the other hand, the L465 showed the lowest value for head diameter $(16.07 \mathrm{~cm}), 100$-seed weight (4.76 g), seed yield /plant (39.76 g) and seed yield /Fedden (1005.31 kg), while it was earlier in $50 \%$ flowering (44.37 days). This varied range of difference is available in the present materials that can help the Egyptian breeder in any breeding program to selection for earliness. 
Table 5. Effect of sunflower genotypes on growth characters in the two season of 2017 and 2018 and their combined

\begin{tabular}{|c|c|c|c|c|c|c|c|}
\hline $\begin{array}{r}\text { Traits } \\
\text { Genotypes }\end{array}$ & $\begin{array}{c}\text { Days to } \\
50 \% \\
\text { flowering }\end{array}$ & $\begin{array}{c}\text { Plant } \\
\text { height }(\mathrm{cm})\end{array}$ & $\begin{array}{c}\text { Stem } \\
\text { diameter } \\
(\mathrm{cm})\end{array}$ & $\begin{array}{c}\text { Head } \\
\text { diameter } \\
(\mathrm{cm})\end{array}$ & $\begin{array}{c}100 \text {-seed } \\
\text { weight }(\mathrm{g})\end{array}$ & $\begin{array}{c}\text { Seed } \\
\text { yield } \\
\text { (g/plant) }\end{array}$ & $\begin{array}{c}\text { Seed yield } \\
\text { (kg/ } \\
\text { fedden) }\end{array}$ \\
\hline \multicolumn{8}{|c|}{2017 season } \\
\hline L990 & 44.89 & 138.55 & 2.10 & 17.96 & 6.17 & 44.94 & 1244.18 \\
\hline L770 & 44.53 & 136.02 & 2.20 & 15.46 & 5.30 & 41.90 & 1143.85 \\
\hline L465 & 43.45 & 147.52 & 2.13 & 17.62 & 4.57 & 39.76 & 996.95 \\
\hline L125 & 45.56 & 148.02 & 2.01 & 17.99 & 5.79 & 43.18 & 1200.40 \\
\hline L460 & 46.15 & 136.62 & 2.25 & 17.89 & 5.61 & 43.68 & 1199.53 \\
\hline L 880 & 45.27 & 149.27 & 2.15 & 17.19 & 4.90 & 39.84 & 1015.14 \\
\hline L120 & 47.47 & 142.76 & 2.03 & 18.62 & 6.67 & 47.90 & 1369.41 \\
\hline Giza 102 & 45.74 & 138.67 & 2.11 & 17.36 & 6.31 & 44.99 & 1273.25 \\
\hline Sakha 53 & 47.10 & 148.34 & 2.19 & 18.21 & 6.39 & 46.87 & 1329.61 \\
\hline LSD & 0.98 & 1.19 & 0.10 & 0.61 & 0.14 & 0.91 & 25.56 \\
\hline \multicolumn{8}{|c|}{2018 season } \\
\hline L990 & 46.40 & 140.38 & 1.92 & 19.37 & 5.53 & 42.02 & 1197.35 \\
\hline L770 & 45.94 & 137.19 & 1.79 & 17.87 & 5.30 & 41.77 & 1092.57 \\
\hline L465 & 45.30 & 148.19 & 2.02 & 14.51 & 4.95 & 39.76 & 1013.66 \\
\hline L125 & 45.85 & 148.69 & 1.76 & 17.69 & 5.50 & 43.70 & 1133.45 \\
\hline L460 & 45.34 & 137.46 & 2.30 & 18.68 & 6.01 & 44.70 & 1242.35 \\
\hline L 880 & 46.09 & 149.78 & 1.86 & 15.87 & 5.16 & 42.38 & 1097.22 \\
\hline L120 & 48.04 & 144.43 & 2.10 & 20.02 & 6.62 & 46.86 & 1352.09 \\
\hline Giza 102 & 46.09 & 139.17 & 1.81 & 17.14 & 6.32 & 43.30 & 1240.19 \\
\hline Sakha 53 & 46.97 & 149.01 & 2.16 & 18.15 & 6.31 & 45.94 & 1283.80 \\
\hline LSD & 0.85 & 0.93 & 0.16 & 0.67 & 0.16 & 0.75 & 13.40 \\
\hline \multicolumn{8}{|c|}{ Combined } \\
\hline L990 & 45.64 & 139.47 & 2.01 & 18.66 & 5.85 & 43.48 & 1220.76 \\
\hline L770 & 45.23 & 136.60 & 2.00 & 16.67 & 5.30 & 41.83 & 1118.19 \\
\hline L465 & 44.37 & 147.86 & 2.07 & 16.07 & 4.76 & 39.76 & 1005.31 \\
\hline L125 & 45.71 & 148.35 & 1.88 & 17.84 & 5.65 & 43.44 & 1166.94 \\
\hline L460 & 45.74 & 137.04 & 2.27 & 18.28 & 5.81 & 44.19 & 1220.94 \\
\hline L 880 & 45.68 & 149.52 & 2.00 & 16.53 & 5.03 & 41.11 & 1056.19 \\
\hline L120 & 47.75 & 143.60 & 2.06 & 19.32 & 6.65 & 47.38 & 1360.75 \\
\hline Giza 102 & 45.92 & 138.92 & 1.96 & 17.25 & 6.32 & 44.14 & 1256.72 \\
\hline Sakha 53 & 47.03 & 148.67 & 2.18 & 18.18 & 6.35 & 46.41 & 1306.72 \\
\hline LSD & 0.90 & 0.74 & 0.09 & 0.44 & 0.10 & 0.58 & 14.15 \\
\hline
\end{tabular}

Concerning L 880 recorded tallest plant height $(149.52 \mathrm{~cm})$, while the shortest genotype was L770 $(136.60 \mathrm{~cm})$. L460 had the highest value for stem diameter (2.27 $\mathrm{cm})$, but the lowest value $(1.88 \mathrm{~cm})$ was detected by L125. These results are in agreement with the findings of Hladni et al. (2012) and Makanda et al. (2012).

\subsection{Chemical composition of seeds}

In both seasons and their combined study, sunflower genotypes significantly differed in all chemical composition of sunflower seeds characters, as shown in (Table 6). In terms of seed oil content, L120 was the best, followed by Sakha 53, and L465 was lowest value. 
Table 6. Effect of sunflower genotypes on oil percentage (\%), total protein (\%) and fatty acid composition (\%) in the two season of 2017 and 2018 and their combined

\begin{tabular}{|c|c|c|c|c|}
\hline Genotypes & $\begin{array}{c}\text { Oil percentage } \\
(\%)\end{array}$ & Total protein $(\%)$ & $\begin{array}{c}\text { Saturated fatty acid } \\
(\%)\end{array}$ & $\begin{array}{l}\text { Unsaturated fatty acid } \\
(\%)\end{array}$ \\
\hline \multicolumn{5}{|c|}{2017 season } \\
\hline L990 & 38.48 & 18.66 & 15.88 & 84.12 \\
\hline L770 & 40.34 & 17.96 & 14.56 & 85.44 \\
\hline L465 & 36.42 & 19.47 & 15.15 & 84.85 \\
\hline L125 & 38.93 & 18.49 & 14.95 & 85.05 \\
\hline L460 & 39.59 & 18.20 & 14.89 & 85.11 \\
\hline L 880 & 40.21 & 17.52 & 15.34 & 84.66 \\
\hline L120 & 42.12 & 17.03 & 14.67 & 85.33 \\
\hline Giza 102 & 37.84 & 19.28 & 14.85 & 85.15 \\
\hline Sakha 53 & 40.80 & 17.40 & 14.18 & 85.82 \\
\hline LSD & 0.35 & 0.26 & 0.19 & 0.19 \\
\hline \multicolumn{5}{|c|}{2018 season } \\
\hline L990 & 39.51 & 18.38 & 15.78 & 84.22 \\
\hline L770 & 40.40 & 17.90 & 14.50 & 85.50 \\
\hline L465 & 37.61 & 19.47 & 15.31 & 84.69 \\
\hline L125 & 40.51 & 17.53 & 15.71 & 84.29 \\
\hline L460 & 39.49 & 18.87 & 15.50 & 84.50 \\
\hline L 880 & 39.66 & 17.84 & 14.60 & 85.40 \\
\hline L120 & 41.20 & 17.15 & 15.25 & 84.75 \\
\hline Giza 102 & 38.68 & 19.21 & 14.67 & 85.33 \\
\hline Sakha 53 & 41.01 & 18.40 & 14.32 & 85.68 \\
\hline LSD & 0.29 & 0.18 & 0.79 & 0.79 \\
\hline \multicolumn{5}{|c|}{ Combined } \\
\hline L990 & 39.00 & 18.52 & 15.83 & 84.17 \\
\hline L770 & 40.38 & 17.93 & 14.53 & 85.47 \\
\hline L465 & 37.01 & 19.47 & 15.23 & 84.77 \\
\hline L125 & 39.71 & 18.01 & 15.33 & 84.67 \\
\hline L460 & 39.53 & 18.53 & 15.20 & 84.81 \\
\hline L 880 & 39.93 & 17.69 & 14.97 & 85.03 \\
\hline L120 & 41.66 & 17.09 & 14.96 & 85.04 \\
\hline Giza 102 & 38.26 & 19.25 & 14.76 & 85.24 \\
\hline Sakha 53 & 40.90 & 17.90 & 14.25 & 85.75 \\
\hline LSD & 0.31 & 0.15 & 0.40 & 0.39 \\
\hline
\end{tabular}

However L465 gave the high protein percentage, but L120 was the lowest one. While. Sakha 53 was the highest proportion from unsaturated fatty acids but it's recorded the lowest proportion from saturated fatty acid. These findings are in accordance with those obtained by Ibrahim (2012) and Abd EL-Satar et al., (2017).

\subsection{Interactions effects \\ 3.3.1. Yield and yield components}

Finally, according to the combined analysis in (Table 7) and (fig 1), the interactive impact of irrigation systems (drip and sprinkler) with sunflower genotypes was important for yield 
Table 7. Effect of the interaction between irrigation systems (Sprinkler and Drip) and sunflower genotypes on growth characters (combined over the two seasons)

\begin{tabular}{|c|c|c|c|c|c|c|c|c|}
\hline Traits & \multicolumn{2}{|c|}{ Days to $50 \%$ flowering } & \multicolumn{2}{|c|}{ Plant height $(\mathrm{cm})$} & \multicolumn{2}{|c|}{ Stem diameter $(\mathrm{cm})$} & \multicolumn{2}{|c|}{ Head diameter $(\mathrm{cm})$} \\
\hline Genotypes & Sprinkler & Drip & Sprinkler & Drip & Sprinkler & Drip & Sprinkler & Drip \\
\hline L990 & 43.61 & 48.24 & 138.21 & 140.72 & 2.09 & 1.93 & 17.62 & 18.73 \\
\hline L770 & 44.30 & 46.17 & 135.85 & 137.35 & 2.12 & 1.87 & 16.64 & 16.70 \\
\hline L465 & 43.33 & 46.94 & 146.69 & 149.03 & 1.95 & 2.00 & 16.36 & 16.78 \\
\hline L125 & 44.84 & 46.57 & 146.52 & 147.19 & 1.72 & 2.10 & 16.83 & 17.85 \\
\hline L460 & 44.77 & 46.72 & 136.12 & 137.96 & 2.15 & 2.03 & 18.38 & 18.19 \\
\hline L 880 & 44.57 & 46.79 & 149.77 & 149.28 & 1.87 & 2.14 & 16.22 & 16.83 \\
\hline L120 & 45.26 & 48.25 & 142.09 & 145.10 & 2.00 & 2.09 & 18.63 & 19.59 \\
\hline Giza 102 & 45.45 & 46.38 & 137.67 & 140.17 & 1.83 & 2.09 & 17.30 & 17.19 \\
\hline Sakha 53 & 46.73 & 47.34 & 147.51 & 149.84 & 2.16 & 2.20 & 18.61 & 17.75 \\
\hline LSD & \multicolumn{2}{|c|}{0.90} & \multicolumn{2}{|c|}{1.05} & 0.1 & & \multicolumn{2}{|c|}{0.62} \\
\hline Traits & \multicolumn{3}{|c|}{ 100-seed weight $(\mathrm{g})$} & \multicolumn{2}{|c|}{ Seed yield (g/plant) } & \multicolumn{3}{|c|}{ Seed yield (kg/ Fedden) } \\
\hline Genotypes & \multicolumn{2}{|l|}{ Sprinkler } & Drip & prinkler & Drip & \multicolumn{2}{|c|}{ Sprinkler } & Drip \\
\hline L990 & 5.71 & 5. & & 0.21 & 46.74 & 1213 & & 7.96 \\
\hline L770 & 5.32 & 5. & & 9.01 & 44.66 & 1126 & & 9.86 \\
\hline L465 & 5.16 & 4. & & 7.82 & 41.70 & 1013 & & 7.54 \\
\hline L125 & 5.50 & 5. & & 9.56 & 47.32 & 1130 & & 2.91 \\
\hline L460 & 5.68 & 5. & & 1.13 & 47.24 & $120 s$ & & 2.38 \\
\hline L 880 & 4.36 & 5. & & 6.02 & 45.70 & 988 & & 3.64 \\
\hline L120 & 6.53 & 6. & & 3.26 & 51.50 & 135 & & 9.60 \\
\hline Giza 102 & 6.20 & 6. & & 9.91 & 48.38 & 1240 & & 3.23 \\
\hline Sakha 53 & 6.20 & 6. & & 3.08 & 49.74 & 1287 & & 5.83 \\
\hline LSD & & 14 & & & & & 20.00 & \\
\hline
\end{tabular}

and yield attributes. The longest time to $50 \%$ flowering (48.25 days) was obtained by sowing sunflower L120 with drip irrigation,

but the tallest plant height $(149.84 \mathrm{~cm})$ and the largest stem diameter $(2.20 \mathrm{~cm})$ was resulting with sowing sunflower Sakha 53 with drip irrigation. The largest head diameters $(19.59 \mathrm{~cm})$, heaviest weight of 100 -seed $(6.76 \mathrm{~cm})$ and seed /plant $(51.50 \mathrm{~g})$ and the highest seed yield / fedden $(1369.60 \mathrm{~kg})$ obtained by sowing sunflower promising line of L 120 under the same system irrigation.
As can be seen in the pooled data in Table (7) and (fig 1), early flowering (43.33 day) obtained by sowing sunflower promising line of L465, the shorter plant $(135.85 \mathrm{~cm})$ was recorded when grown L770, the lowest stem diameter $(1.72 \mathrm{~cm})$ was recorded when grown L125, while the lowest values of head diameter $(16.22 \mathrm{~cm}), 100$-seed weight (4.36 g), seed yield /plant (36.02 g) and hence seed yield /fedden $(988.78 \mathrm{~kg})$ were obtained by grown sunflower L880 under sprinkler irrigation system. 


\subsubsection{Chemical composition of seeds}

The interaction between irrigation systems and tested sunflower genotypes as the average of both seasons in (Table 8) and (fig 2), revealed that the drip irrigation system, a combination of grown L120 and L465 produced the highest content of oil in seed and the lowest total protein content, while Giza102 produced the highest total protein content (19.20) at the sprinkler irrigation system. and the highest proportion of unsaturated fatty acids came from better oil content at the drip irrigation system with sowing sunflower L120.

Table 8. Effect of the interaction between irrigation systems and sunflower genotypes on oil percentage (\%), total protein (\%) and fatty acids composition (\%) (combined over the two seasons)

\begin{tabular}{|c|c|c|c|c|c|c|c|c|}
\hline Traits & \multicolumn{2}{|c|}{ Oil percentage $(\%)$} & \multicolumn{2}{|c|}{ Total protein $(\%)$} & \multicolumn{2}{|c|}{$\begin{array}{c}\text { saturated fatty acid } \\
(\%)\end{array}$} & \multicolumn{2}{|c|}{$\begin{array}{c}\text { Unsaturated fatty acid } \\
(\%)\end{array}$} \\
\hline Genotypes & Sprinkler & Drip & Sprinkler & Drip & Sprinkler & Drip & Sprinkler & Drip \\
\hline L990 & 39.21 & 38.79 & 17.60 & 18.44 & 16.18 & 14.72 & 83.82 & 85.28 \\
\hline L770 & 40.16 & 40.58 & 18.22 & 18.64 & 14.92 & 14.44 & 85.08 & 85.56 \\
\hline L465 & 41.59 & 41.72 & 17.40 & 16.78 & 14.85 & 14.43 & 85.15 & 85.57 \\
\hline L125 & 39.70 & 39.73 & 17.05 & 17.96 & 14.98 & 13.98 & 85.02 & 86.02 \\
\hline L460 & 39.18 & 39.88 & 17.75 & 18.32 & 15.43 & 14.81 & 84.57 & 85.19 \\
\hline L 880 & 36.78 & 40.05 & 17.42 & 17.93 & 15.21 & 14.96 & 84.79 & 85.04 \\
\hline L120 & 40.25 & 41.82 & 18.50 & 16.45 & 14.34 & 13.71 & 85.66 & 86.29 \\
\hline Giza 102 & 38.21 & 38.31 & 19.20 & 18.24 & 15.06 & 14.45 & 84.94 & 85.55 \\
\hline Sakha 53 & 39.18 & 40.62 & 18.41 & 17.40 & 14.80 & 13.82 & 85.20 & 86.18 \\
\hline LSD & \multicolumn{2}{|c|}{0.31} & \multicolumn{2}{|c|}{0.22} & \multicolumn{2}{|c|}{0.56} & \multicolumn{2}{|c|}{0.20} \\
\hline
\end{tabular}



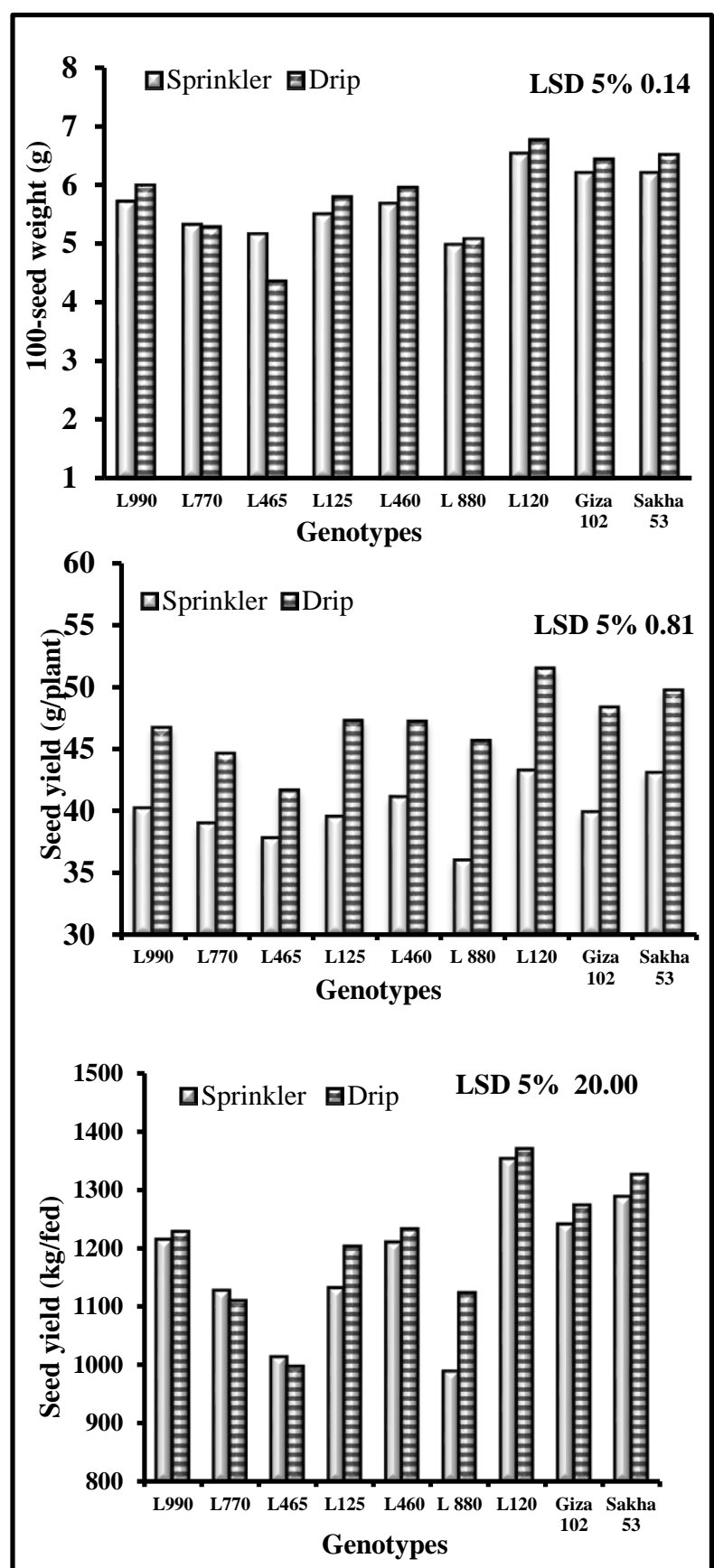

Fig 1. Effect of interaction between irrigation systems (Sprinkler and drip) and sunflower genotypes on crop yield (combined over the two seasons).

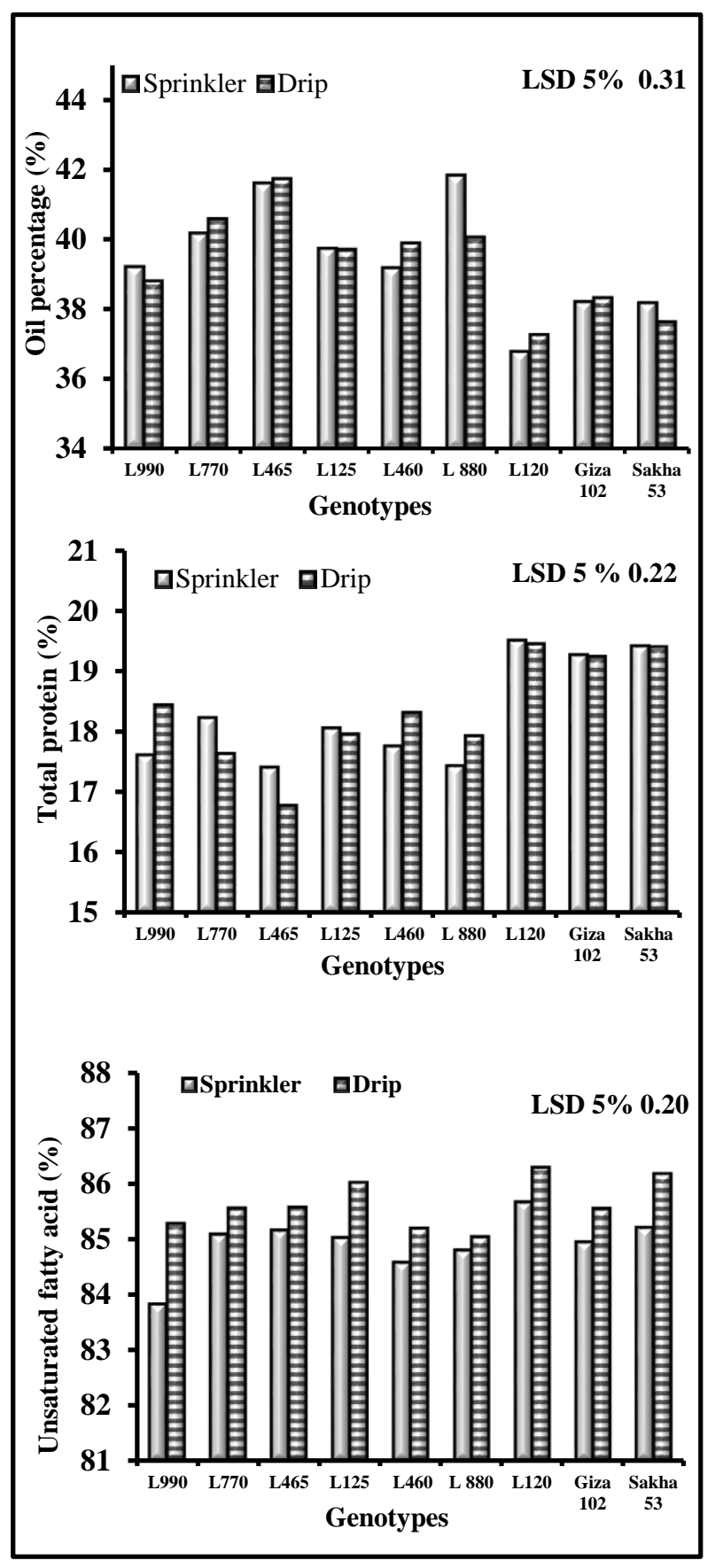

Fig 2. Effect of interaction between irrigation systems (Sprinkler and drip) and sunflower genotypes on chemical probertites (combined over the two seasons). 


\section{Conclusion}

The results of study revealed that drip irrigation method has potential to increase the production of sunflower genotypes and highest content and better quality of oil. Also, the largest head diameters, 100 -seed weight, seed yield /plant, seed yield /fedden, and oil content in seed were all reported by L 120 . and gave the better oil quality represented the highest proportion from unsaturated fatty acids at drip irrigation system.

\section{References}

A.O.A.C. (1990) 'Official Methods of Analysis of the Association Official Analytical Chemists' $15^{\text {th }}$ Edition. Washington' D.C. USA.

A.O.A.C. (2000) 'Official Methods of Analysis Association of Official Analytical Chemist, EUA.

A.O.A.C. (2005). Official Methods of Analysis of Association of Official Analytical Chemist $18^{\text {th }}$ Edition, Washington, D.C. USA.

Abd EL-Satar M. A, A. A Ahmed; T. H. A. Hassan (2017) 'Response of seed yield and fatty acid compositions for some sunflower genotypes to plant spacing and nitrogen fertilization' Egypt Info Proc Agri 241-252.

Abdul Latif, Q., A. G. Mumtaz, A. M. Ali, A. M. Nisar, A. Soomro and H.M. Aneela (2015) 'Effect of Drip and Furrow Irrigation Systems on Sunflower Yield and Water Use Efficiency in Dry Area of Pakistan' American-Eurasian J. Agric. \& Environ. Sci., 15 (10): pp 1947-1952.

Demirer, T., Özer, I., Koçtürk, Ö.M. and Yesilyurt, Er.A., (2004) 'Effect of Different Leaf Fertilizers on Yield and Quality in Sunflower (Helianthus annuus L.)' Pakistan Journal of Biological Sciences 7(3): 384-388.

Fernandez - Martinez, J., Velasco, L. and Perez - Vich, B., (2004) 'Progress in the genetic modification of sunflower oil quality' Proc. of $16^{\text {th }}$ International Sunflower Conference, Fargo, ND USA,

Fick, GN., (1989) 'Sunflower. In: Oil Crops of the World': Rbbelen G, Downey RK, Ashri A (eds.). McGraw-Hill, New York,

Gomez K.A. and Gomez A.A. (1984) 'Statistical Procedures for Agricultural Research' $2^{\text {nd }}$ Ed., New York: John Willey and Sons, Inc

Hladni, N., Dedić, B., Jocić, S., Miklič, V. and Dušanić, N., (2012). 'Evaluation of resistance of new sunflower hybrids to broomrape in the breeding programs in Novi Sad' Helia 35(56): 89-98.

Hu, J., Seiler, G. and Kole, C., (2010). 'Genetics, genomics and breeding of sunflower' Routledge, USA, 342.

Ibrahim H.M. (2012) 'Response of some sunflower hybrids to different levels of plant density' APCBEE Proc ,4:175-82. 
Karaaslan, D., Hatipoglu, A., Türk, Z. and Kaya, Y., (2010) 'Determination of potential sunflower cultivars (Helianthus annuus L.) cultivars for the irrigated conditions of Diyarbakir' Helia 33(52): 145-152.

Kassab, O.M., Abo Ellil, A.A and Abo ElKheir, M.S.A. (2012) 'Water use efficiency and productivity of two sunflower cultivars as influenced by three rates of drip irrigation water' Egypt, Journal of Applied Sciences Research. (7): 3524-3529.

Keshta, M.M., Rizk, T.Y. and Abdou, E.T., (2008) 'Sunflower response to mineral nitrogen, organic and bio-fertilizers under two different levels of salinity' In: Velasco, L. (ed.), Proceedings of the $17^{\text {th }}$ International Sunflower Conference, Cordoba, Spain, June 8-12, 451-454.

Killi, F. and Altunbay, S.G., (2005) 'Seed Yield, Oil Content and Yield Components of Confection and Oilseed Sunflower (Helianthus annuus L.) Cultivars Planted in Different Dates' Journal of Agriculture and Biology 7(1): 21-24.

Makanda, I., Matamela, T., Mashingaidze, K., Chigeza, G., Musanya, J. and Muungani, D., (2012) 'Breeding investigations into the gene action and agronomic performance of sunflower traits based on $\mathrm{F}_{1}$ top-cross hybrids' Helia 35(56): 31-40.
Merren A. and Champolivier L., (1992) 'Applications of ethephon on sunflower to prevent lodging' Proceedings of 13 th International Sunflower Conference, Pisa, Italy, 593-596.

Nagarathna, T.K., Shadakshari, Y.G., Ramakrishna Parama, V.R., Jagadish, K.S. and Puttarangaswamy, K.T., (2012) 'Examination of root characters, isotope, discrimination, physiological and morphological traits and their relationship used to identify the drought tolerant sunflower (Helianthus annuus L.) genotypes' Hellia 35(56): 1-8.

Page, A.L., Miller R.H., and Keeney, D.R. (1982) 'Methods of Soil Analysis' Part 2 Soil Soc. Amer. Inc., Madison, Wisconsin, U.S.A.

Putt, E., (1997) 'Early History of Sunflower: American Society of Agronomy, Madison, Wis. (USA). 1-19.

Sadghi, M., Seyed Sharifi, R., Namvar, A., Khandan-e-Bejandi, T. and Molaei, P., (2008) 'Responses of Sunflower Yield and Grain Filling Period to Plant Density and Weed Interference' Research Journal of Biological Sciences 3(9): 1048-1053.

Zygadlo J.A., Morere R.E., Abburra R.E., Guzman C.A. (1994) 'Fatty acids composition in seed oils of some on agracaea' J Am Oil Chem Soc., 1994; 71:915-6. 